\title{
PENGARUH TEAM TEACHING TERHADAP HASIL BELAJAR PEMROGRAMAN WEB SISWA KELAS X SMK MALAKA JAKARTA
}

\author{
Arindy $^{1}$, Sukardjo $^{2}$, Aodah Diamah ${ }^{3}$ \\ ${ }^{1}$ Mahasiswa Prodi Pendidikan Teknik Elektronika Fakultas Teknik Universitas Negeri Jakarta \\ ${ }^{2,3}$ Dosen Prodi Pendidikan Teknik Elektronika Fakultas Teknik Universitas Negeri Jakarta \\ E-mail: ${ }^{1}$ arindymhd@gmail.com² asukardjo@yahoo.com ${ }^{3}$ adiamah@unj.ac.id
}

\begin{abstract}
Abstrak - Tujuan penelitian adalah untuk mengetahui pengaruh penerapan team teaching pada materi pokok format teks halaman web terhadap hasil belajar siswa kelas X TKJ 1 SMK Malaka Jakarta.Penelitian yang dilakukan merupakan penelitian pra eksperimental dengan model onegroup pre-test post-test design. Sampel penelitian diambil secara acak sebanyak 30 siswa. Perlakuan yang diberikan pada siswa yaitu siswa diajar menggunakan metode pembelajaran team teaching (tim pengajar). Sebelum diberi perlakuan, siswa diberikan pre-test untuk mengetahui kemampuan awal siswa, kemudian setelah diberi perlakuan siswa diberikan post-test untuk mengetahui sejauh mana peningkatan hasil belajar siswa. Instrumen pengumpulan data berupa tes, pada tes ini soal-soal diberikan dalam bentuk pilihan ganda.Instrumen pengumpulan data berupa tes, pada tes ini soal-soal diberikan dalam bentuk pilihan ganda. Dari hasil analisa data pada uji hipotesis didapat harga $t_{\text {hitung }}$ yaitu 25,15 dan $t_{\text {tabel }}$ untuk satu pihak yaitu 2,462, bila dibandingkan antara $t_{\text {hitung }}$ dan $t_{\text {tabel }}$ maka $t_{\text {hitung }}>t_{\text {tabel }}$ atau 25,15 $>2,462$. Kesimpulan yang dapat diambil adalah terdapat pengaruh terhadap hasil belajar siswa yang diajar menggunakan metode pembelajaran team teaching, khususnya untuk materi pokok format teks halaman web.

Kata Kunci : Metode, Pembelajaran, Pengaruh, Team Teaching, hasil belajar, SMK Malaka
\end{abstract} Jakarta.

Abstract - The purpose of this research is to know the influence of the implementation of team
teaching on the subject matter of the text format of the web page to the learning result of the
students of class X TKJ 1 SMK Malaka Jakarta. The research is an experimental pre experiment
with one-group pre-test post-test design. The sample was taken randomly as many as 30 students.
The treatment given to students is that students are taught using Teaching Teaching Method
(Teaching Teams). Before being treated, students are given a pre-test to determine the students'
initial ability, then after being given the students treatment is given a post-test to find out how far
the improvement of student learning outcomes. Instrument data collection in the form of test, in
this test the questions are given in the form of multiple choice. From the results of data analysis on
the hypothesis test obtained price of $t_{\text {count }}$ is 25,15 and $t_{\text {table }}$ for one party is 2.462 , when
compared between $t_{\text {count }}$ and $t_{\text {table }}$, then $t_{\text {count }}>t_{\text {table }}$ or $25,15>2,462$. The conclusion that can be taken is there is an influence on the learning outcomes of students who are taught using teaching team teaching methods, especially for the subject matter of text format web pages.

Keywords: Method, Learning, Influence, Team Teaching, learning outcomes, SMK Malaka Jakarta.

\section{PENDAHULUAN}

Seiring berkembangnya kurikulum pendidikan di Indonesia, maka bertambah pula tuntutan-tuntutan bagi guru dalam mengimplementasikan kurikulum tersebut dalam proses belajar mengajar. Saat ini guru guru dituntut untuk lebih kreatif dan inovatif 
dalam memilih metode pembelajaran yang digunakan dan disesuaikan dengan materi pelajaran yang akan disampaikan kepada siswa. Terlebih khusus lagi guru harus memperhatikan kebutuhan dan perbedaan individu siswa. Para guru tentunya menyadari menghadapi banyak siswa di dalam kelas, berarti juga menghadapi banyak macam keunikan atau karakteristik.

Menurut Dimyati dan Mudjiono (2013:66), setiap guru tentunya harus menyadari bahwa menghadapi 30 siswa dalam satu kelas, berarti menghadapi 30 macam keunikan atau karakteristik. Selain karakteristik/keunikan kelas, guru harus menghadapi 30 siswa yang berbeda karakteristiknya satu dengan lainnya. Guru sebagai penyelenggara kegiatan pembelajaran dituntut untuk memberikan perhatian kepada semua keunikan yang melekat pada tiap siswa. Dengan kata lain, guru tidak mengasumsikan bahwa siswa dalam kegiatan pembelajaran yang diselenggarakannya merupakan satu kesatuan yang memiliki karakteristik yang sama. Konsekuensi logis adanya hal ini, guru harus mampu melayani setiap siswa sesuai karakteristik mereka orang per orang, pembelajaran seperti ini disebut pembelajaran individual dari segi kebutuhan pelajar, pembelajaran individual lebih efektif, sebab siswa belajar dengan programnya sendiri. Dari segi guru, yang terkait dengan jumlah pebelajar, tampak kurang efisien. Jika hanya ada satu guru yang mengajar di dalam kelas, maka pembelajaran individual akan kurang efisien. Jadi, permasalahannya adalah apakah mungkin seorang guru dapat memberikan pembelajaran individual kepada satu kelas siswa dengan materi yang cukup padat dan waktu pembelajaran yang cukup singkat. Selain itu, dengan kondisi kelas yang besar dan murid yang banyak guru akan kesulitan untuk melakukan pembelajaran individual .

Berdasarkan hasil obeservasi di SMK Malaka Jakarta, tingkat pemahaman siswa pada mata pelajaran pemrograman web pun masih kurang jika hanya menggunakan metode ceramah hal ini dibuktikan oleh hasil UTS semester ganjil (2016/2017) yang masih dibawah KKM, selain itu observasi menunjukan kurangnya keaktifan siswa dalam hal mengemukakan pendapat selama kegiatan belajar mengajar, ini mengindikasikan bahwa guru memerlukan rekan yang mampu diajak bekerja sama dalam menghadapi segala kesulitan dalam melaksanakan proses pembelajaran.

Dalam hal ini, team teaching tampaknya bisa dijadikan sebagai alternatif untuk mengatasi permasalahan yang merupakan salah satu bentuk pembelajaran yang melibatkan dua orang guru atau lebih dalam proses pembelajaran. Team teaching ini dilaksanakan dengan tujuan untuk membantu siswa agar lebih baik dalam belajar, juga meringankan guru sehingga bisa bertanggung jawab bersama terhadap pelajaran yang diberikan, dapat saling membantu antar guru, meningkatkan kerja sama, saling mengisi, dan saling memikirkan bersama pengembangan mata pelajaran.

Peneliti hendak meneliti apakah team teaching dapat mempengaruhi hasil belajar Pemrograman Web siswa pada materi pokok format teks halaman web mengingat materi pokok tersebut merupakan pokok bahasan yang paling dasar dan sangat penting dalam mata pelajaran Pemrograman Web.

Dari latar belakang di atas, maka gagasan pembelajaran individual dengan menerapkan team teaching menurut saya sangat bermanfaat untuk diteliti, dengan judul penelitian "Pengaruh Team Teaching Terhadap Hasil Belajar Pemrograman Web Siswa Kelas X Teknik Komputer dan Jaringan SMK MALAKA JAKARTA “

\section{METODOLOGI PENELITIAN}

Lokasi penelitian ini dilaksanakan di kelas X TKJ 1 SMK Malaka Jakarta yang terletak di Jalan Mawar merah no.23 Pondok Kopi, Jakarta Timur. Waktu pelaksanaan penelitian ini dilakukan pada semester genap tahun pelajaran 2016/2017, sejak tanggal 21 April hingga 26 Mei 2017 di SMK Malaka Jakarta. Subjek dari penelitian ini adalah siswa kelas X TKJ 1 di SMK Malaka Jakarta, tahun pelajaran 2016/2017 yang akan diberikan perlakuan penerapan metode pembelajaran team teaching dengan jumlah siswa sebanyak 30 orang. Populasi penelitian ini adalah seluruh siswa kelas X TKJ SMK Malaka Jakarta yang terdiri dari 2 kelas. Sampel penelitian adalah sebagian dari populasi, pengambilan sampel penelitian ini dilakukan dengan cara 
mengambil satu kelas secara acak dari kedua kelas yang menjadi populasi yang akan diterapkan metode team teaching dalam penelitian ini.

Metode penelitian yang digunakan dalam penelitian ini adalah pra eksperimental dengan model one-group pretest post-test design yang dapat digambarkan pada tabel 3.1 sebagai berikut (Sugiyono, 2013: 111):

Tabel 1. Desain Penelitian (one- group pretestposttest design)

\begin{tabular}{|ccc|}
\hline $\mathrm{O}_{1}$ & $\mathrm{X}$ & $\mathrm{O}_{2}$ \\
\hline
\end{tabular}

Keterangan :

$\mathrm{X}$ : Perlakuan dengan menerapkan metode team teaching

$\mathrm{O}_{1}$ : skor pre-test untuk kelas eksperimen

$\mathrm{O}_{2}$ : skor post-test untuk kelas eksperimen

\section{A. Perlakuan Penelitian}

1) Ada beberapa prosedur perlakuan dalam penelitian ini yaitu :

2) Dari dua kelas dipilih dengan cara acak satu kelas sebagai sampel penelitian, kelas yang dijadikan sampel adalah kelas TKJ 1.

3) Semua siswa kelas TKJ 1 (sampel) diberi pre-test untuk mendapatkan data hasil belajar siswa sebelum penelitian. Hasil pre-test kelas TKJ 1 ini diuji dengan uji normalitas.

4) Siswa diberikan perlakuan dengan pembelajaran yang diajar oleh team teaching (tim pengajar).

5) Pada akhir bab materi pelajaran siswa diberikan postest untuk melihat kemampuan siswa dan untuk membandingkan hasil belajar siswa antara hasil pre-test dan post-test siswa.

6) Setelah semua data hasil belajar didapatkan maka untuk mendapatkan apakah perbedaan hasil belajar antara pre-test dan post-test itu signifikan atau tidak, maka data diuji dengan uji-t .

\section{B. Instrumen Penelitian}

Untuk melihat hasil belajar siswa, dalam penelitian ini digunakan dua macam tes, yaitu : a. Pre-test, yaitu tes yang diberikan sebelum pengajaran dimulai dan bertujuan untuk mengetahui sampai dimana penguasaan siswa terhadap bahan pengajaran yang akan di ajarkan.

b. Post-test, yaitu tes yang diberikan pada setiap akhir program satuan pengajaran. Tujuan post-test adalah untuk mengetahui sampai dimana pencapaian siswa terhadap bahan pengajaran setelah mengalami suatu kegiatan belajar. Perbandingan hasil pretest dan post-test menunjukkan sejauh mana kefektifan pelaksanaan program pengajaran terhadap hasil belajar siswa (Purwanto, 1997 : 28). Tes hasil belajar yang diungkapkan dalam penelitian ini adalah aspek pengetahuan dan pemahaman (kognitif) pada saat teori yang mengguanakan uji validitas. Kisi-kisi Instrumen penelitian dapat dilihat pada lampiran 3 .

\section{Uji Analisis Data Statistik}

Uji Analisis Data Statistik dengan menggunakan teknik t-test. Bila data yang diperoleh terdistribusi normal, maka statistik $\mathrm{t}$ yang digunakan pada penelitian adalah dengan menggunakan uji-t satu kelompok (Subana,dkk., $2005:$ 132):

$$
t=\frac{M d}{\sqrt{\frac{\sum d^{2}-\frac{\sum d^{2}}{n}}{n(n-1)}}}
$$

Keterangan:

$$
\begin{aligned}
\mathrm{Md}= & \begin{array}{r}
\text { rata-rata dari gain tes pre-test dan } \\
\text { post-test }
\end{array} \\
\mathrm{d} \quad= & \text { gain (selisih) skor tes akhir terhadap } \\
& \text { tes awal setiap subjek. } \\
\mathrm{n} \quad= & \text { jumlah subjek }
\end{aligned}
$$

\section{Hipotesis Statistik}

Perumusan Hipotesis dalam penelitian ini adalah:

$$
\begin{aligned}
H_{0}: \mu_{1}= & \mu_{2} \\
& H_{1}: \mu_{1}>\mu_{2}
\end{aligned}
$$

1. Tolak $H_{0}: \mu_{1}>\mu_{2}$, artinya terdapat pengaruh terhadap hasil belajar Pemrograman Web siswa dengan diterapkan metode Team Teaching. 
2. Terima $H_{0}: \mu_{1}=\mu_{2}$, artinya tidak terdapat pengaruh terhadap hasil belajar Pemrograman Web siswa dengan diterapkan metode Team Teaching.

Keterangan:

$H_{0}=$ Hipotesis nol

$H_{1}=$ Hipotesis Kerja

$\mu_{1}=$ Hasil nilai rata-rata pre-test kelas TKJ 1.

$\mu_{2}=$ Hasil nilai rata-rata post-test kelas TKJ 1

\section{HASIL DAN PEMBAHASAN}

\section{A. Deskripsi Data}

\section{1) Hasil belajar pre-test}

Berdasarkan rekapitulasi hasil belajar pre-test (lampiran 4), maka didapatkan hasil analisis statistik deskripsi data hasil belajar pre-test dengan perolehan rerata kelas (mean) sebesar 38, median sebesar 37,5, varians sebesar 65,6 dan standar deviasi sebesar 8,1. Hasil deskrepsi data kemudian dibuat dalam bentuk tabel distribusi frekuensi agar dapat diketahui seberapa banyak penyebaran hasil belajar pre-test. Hasil perhitungan dan tabel distribusi frekuensi secara lengkap dapat dilihat pada lampiran 5.

\section{2) Hasil belajar post-test}

Berdasarkan rekapitulasi hasil belajar post-test lampiran 5, diperoleh hasil analisis statistik deskrepsi data hasil belajar posttest kelas eksperimen dengan perolehan rerata kelas (mean) sebesar 85,33; median sebesar 83; varians sebesar 69,70; dan standar deviasi sebesar 8,35. Dari hasil deskripsi data tersebut dapat dibuat ke dalam tabel distribusi frekuensi sehingga penyebaran hasil belajar post-test dapat diketahui seberapa banyak penyebarannya. Secara lengkap perhitungan dan tabel distribusi frekuensi dapat dilihat pada lampiran 5.

\section{B. Pengujian Persyaratan Analisis}

Sebelum pengujian hipotesis dilakukan, terlebih dahulu dilakukan uji persyaratan analisis. Pengujian persyaratan analisis data dalam penelitian ini meliputi uji normalitas dan homogenitas. Hasil uji persyaratan analisis lebih lanjut akan dibahas sebagai berikut :

1) Uji normalitas

Uji normalitas dilakukan dengan menggunakan chi kuadrat $\left(\chi^{2}\right)$ dengan taraf signifikansi $5 \%$. Hasil perhitungan chi kuadrat hitung kemudian dibandingkan dengan chi kuadrat tabel sehingga dari hasil perbandingan tersebut dapat diketahui apakah sebaran data berdistribusi normal atau tidak. Apabila hasil chi kuadrat $\left(\chi^{2}\right)$ hitung lebih kecil dari chi kuadrat $\left(\chi^{2}\right)$ tabel maka data sebaran variabel dinyatakan berdistribusi normal. Hasil perhitungan analisis uji normalitas secara rinci dapat dilihat pada lampiran 6 .

Berikut disajikan ke dalam tabel 4.4 mengenai hasil perhitungan analisis chi kuadrat hitung dan keputusan normalitas data sebaran setelah dilakukan perbandingan hasil chi kuadrat hitung dengan chi kuadrat tabel.

Tabel 2. Hasil Uji Normalitas Sebaran Data

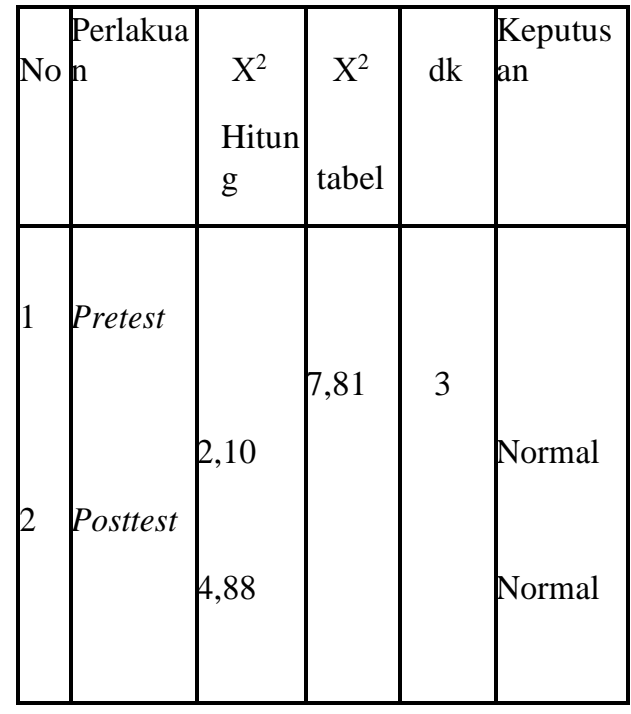

\section{Pengujian Hipotesis}

Berdasarkan deskripsi data dan uji persyaratan analisis, telah menunjukan bahwa data berdistribusi normal, maka pengujian hipotesis dapat dilaksanakan. Pengujian hipotesis dilakukan dengan menggunakan uji-t untuk dua kelompok data dari satu kelompok sampel (berpasangan), berupa pengujian hipotesis uji satu pihak kanan. Hasil perhitungan thitung kemudian dibandingkan dengan ttabel dengan derajat 
kebebasan $(\mathrm{dk})=\mathrm{N}-1$ dengan taraf signifikansi $1 \%$ dan 5\%. Berikut pengujian hipotesis yang akan di uji kebenarannya :

a. Hipotesis

Ho = tidak terdapat pengaruh yang lebih baik teradap hasil belajar siswa yang diajar menggunakan metode pembelajaran team teaching.

$\mathrm{Ha}=$ terdapat pengaruh yang lebih baik teradap hasil belajar siswa yang diajar menggunakan metode pembelajaran team teaching.

b. Keputusan

Mengacu pada hipotesis di atas, apabila diperoleh perbandingan thitung lebih kecil dari ttabel maka Ho diterima dan apabila thitung lebih besar dari ttabel maka Ha diterima. Hasil analisis data secara rinci dapat dilihat pada lampiran 7. Berdasarkan hasil perhitungan t-test dengan manual melalui data analisis diperoleh thitung sebesar 25,15 dan ttabel untuk satu pihak sebesar 2,462 dengan $\mathrm{dk}$ sebesar 29. Dari perolehan hasil thitung tersebut apabila dibandingkan dengan besarnya ttabel, diperoleh hasil perbandingan thitung lebih besar dari ttabel yaitu sebesar 25,15 $>2,462$. Dengan demikian Ho ditolak dan Ha diterima dan dapat dinyatakan bahwa terdapat pengaruh yang lebih baik teradap hasil belajar siswa yang diajar menggunakan metode pembelajaran team teaching. Dengan demikian penggunaan metode pembelajaran team teaching memberikan pengaruh positif terhadap hasil belajar siswa.

\section{Pembahasan Hasil Penelitian}

Pembahasan pada penelitian ini membahas mengenai pengaruh metode pembelajaran team teaching terhadap hasil belajar siswa kelas X TKJ 1 pada materi pokok format teks halaman web dengan jumlah sampel yang diteliti sebanyak 30 responden. Dengan adanya perlakuan yang tersebut diharapkan dapat memberikan pengaruh terhadap hasil belajar pemrograman web siswa. Berikut ini dijelaskan mengenai pengaruh terhadap hasil belajar pre-test dan post-test siswa yang dilihat dari hasil perbandingan rerata dan analisis uji beda (t-tes) :

1) Peningkatan hasil belajar pre-test post -test
Tabel 3. Peningkatan Hasil BelajarPemrograman Web

\begin{tabular}{|c|c|c|c|c|}
\hline & $\begin{array}{c}\text { Nilai } \\
\text { Rerat }\end{array}$ & $\begin{array}{c}\text { Nilai } \\
\text { Rerat } \\
\text { a }\end{array}$ & Penin & Persentase \\
Kelas & $\begin{array}{c}\text { Prete } \\
\text { st }\end{array}$ & $\begin{array}{c}\text { Postt } \\
\text { est }\end{array}$ & $\begin{array}{c}\text { gkata } \\
\text { n }\end{array}$ & Peningkatan \\
\hline $\begin{array}{c}\text { Eksperi } \\
\text { men }\end{array}$ & & & & \\
\hline
\end{tabular}

Mengacu pada tabel data analisis deskriptif di atas terlihat bahwa terdapat peningkatan hasil belajar siswa sebelum mendapatkan perlakuan (treatment) dengan sesudah mendapatkan perlakuan (treatment) menggunakan metode pembelajaran team teaching. Hasil tersebut dapat dilihat dengan persentase peningkatan sebesar 40,3\%. Hal ini dikarenakan pada saat melakukan pre-test siswa belum pernah mendapatkan materi dan setelah mendapatkan materi dari dua orang guru yang berbeda dalam satu team dan dilakukan post-test maka hasil belajar siswa meningkat.

Metode pembelajaran yang digunakan dalam pembelajaran yaitu team teaching dimana dalam satu mata pelajaran diajar dengan dua orang guru yang memiliki pengalaman dan keahlian yang sesuai dengan materi yang akan disampaikan kepada siswa, keuntungan dari metode team teaching adalah beban dari seorang guru dapat berkurang karena tugas untuk menyapaikan materi bisa dibagi bersama, sehingga seorang guru dapat menyampaikan materi secara terpusat dan detail yang akhirnya akan memberikan dampak positif terhadap hasil belajar siswa serta bisa mengontrol siswa dengan lebih baik karena pada saat guru menjelaskan ada guru lain yang mengontrol aktivitas siswa

Perbandingan hasil belajar pre-test lebih tinggi atau lebih rendah dari hasil belajar posttest dilakukan pengujian hipotesis dengan menggunakan t-test komparatif dua kelompok data dari satu kelompok sampel dengan taraf signifikansi $1 \%$ dan 5\%. Dari hasil data pengujian analisis hasil belajar diperoleh thitung sebesar 25,15 dan ttabel untuk satu pihak 
sebesar 2,462 dengan dk sebesar 29. Dari perolehan hasil thitung tersebut apabila dibandingkan dengan besarnya ttabel, diperoleh hasil perbandingan thitung lebih besar dari ttabel yaitu sebesar 25,15>2,462.

Hasil belajar post-test siswa pada mata materi pokok format teks halaman web meningkat dengan menggunakan metode pembelajaran team teaching. Melihat hasil pembahasan di atas maka dapat disimpulkan bahwa terdapat pengaruh positif pada perlakuan menggunakan metode pembelajaran team teaching terhadap hasil belajar pemrograman web siswa.

Penggunaan metode pembelajaran team teaching memungkinkan siswa mendapatkan sumber dan pelajaran dari guru yang berbeda sehingga siswa tidak cepat bosan dan lebih memperhatikan materi yang disampaikan serta dapat memahami materi dengan maksimal. Adapun kekurangannya yaitu faktor yang dapat mempengaruhi hasil belajar siswa tidak hanya terletak pada faktor metode pembelajaran tetapi masih banyak faktor lain yang mempengaruhi hasil belajar yang tidak dikontrol dalam penelitian ini.

Penelitian ini dapat mempertegas penelitian dari Yenni maharany (2011) yang berjudul "Pengaruh Team Teaching Pada Pokok Bahasan Keseimbangan Benda Tegar Terhadap Hasil Belajar Fisika Siswa Kelas XI IPA SMA Srijaya Negara Palembang"'”. Hasil penelitian menunjukan peningkatan aktivitas siswa dalam pembelajaran dan peningkatan prestasi belajar matematika. Terdapat perbedaan yang signifikan pada hasil belajar siswa antara siswa yang diajar dengan team teaching (tim pengajar) dan siswa yang diajar dengan satu orang pengajar dapat dilihat pada perbedaan ratarata nilai post-test siswa. Rata-rata post -test untuk kelas eksperimen adalah 64,5 dan rata-rata post-test untuk kelas kontrol adalah 57,79 , dapat dilihat bahwa rata-rata post-test untuk kelas eksperimen lebih besar dari ratarata post-test untuk kelas kontrol. Dari hasil ini maka peneliti menyatakan bahwa hasil belajar siswa yang diajar dengan team teaching (tim pengajar) lebih baik dari hasil belajar siswa yang diajar dengan satu orang pengajar.

Penelitian ini juga mendukung teori Jamal Ma'mur Asmani dalam bukunya
Micro Teaching dan Team Teaching bahwa "sebuah team dapat pula menggabungkan guru baru dengan guru yang sudah berpengalaman sehingga terjadi leveling mechanism. Guru baru baik sengaja atau tidak dapat belajar dengan guru yang sudah berpengalaman". Selain itu, siswa tidak akan merasa cepat bosan dan akan lebih memperhatikan materi karena pada saat menjelaskan pelajaran ada guru lain yang mengawasi aktivitas mereka. Dengan demikian hipotesis penelitian ini terjawab bahwa terdapat pengaruh yang lebih baik teradap hasil belajar siswa yang diajar menggunakan metode pembelajaran team teaching.

\section{KESIMPULAN}

Berdasarkan hasil penelitian dan pembahasan dapat disimpulkan sebagai berikut, penelitian ini membuktikan bahwa terdapat pengaruh terhadap hasil belajar pemrograman web siswa di SMK Malaka Jakarta dengan menggunakan metode pembelajaran team teaching, dibuktikan dengan peningkatan hasil belajar siswa antara skor pretest dan skor posttest dengan persentase peningkatan sebesar $40,3 \%$.

\section{REFRENSI}

[1] Arikunto, Suharsimi. (2001). Dasardasar Evaluasi Pendidikan. Jakarta: Bumi Aksara.

[2] Asmani, Jamal Ma'mur. (2010). Pengenalan dan Pelaksanaan Lengkap Micro Teaching dan Team Teaching. Jogjakarta : Diva Press.

[3] Dimyati \& Mudjiono. (2006). Belajar dan Pembelajaran. Jakarta : Rineka Cipta.

[4] Hamalik, Oemar. (2001). Proses Belajar Mengajar. Jakarta : Bumi Aksara

[5] Maharany, Y . 2011. Pengaruh Team Teaching Pada Pokok Bahasan Keseimbangan Benda Tegar Terhadap Hasil Belajar Fisika Siswa Kelas XI IPA SMA Srijaya Negara Palembang [skripsi]. Indralaya: Fakultas Keguruan dan Ilmu Pendidikan, Universitas Sriwijaya.

[6] Margono, S. (2004). Metode Penelitian Pendidikan. Jakarta : Rineka Cipta.

[7] Nana, Sudjana. (2008). Penilaian Hasil Proses Belajar Mengajar. Bandung : Remaja Rosdakarya. 
[8] Nasution, S. (2000). Didaktif Asas-asas Mengajar. Jakarta : Bumi Aksara.

[9] Purnomo \& Damayanti. (2013).

Pemrograman Web. Jakarta:

Kementerian Pendidikan \&

Kebudayaan.

[10] Purwanto, N. (1997). Prinsip-prinsip dan Teknik evaluasi 